\title{
Creatinine Clearance in Renal Disease. A Reappraisal
}

\author{
KWAN E. KIM,* M.D.; GADDO ONESTI, $†$ M.D. ; OSVALDO RAMIREZ, $\ddagger$ M.D. \\ ALBERT N. BREST,§ M.D.; CHARLES SWARTZ,\| M.D.
}

British Medical fournal, 1969, 4, 11-14

\begin{abstract}
Summary: To determine the validity of endogenous creatinine clearance as a measure of glomerular filtration rate in patients with renal disease 308 simultaneous determinations of inulin clearance and endogenous creatinine clearance were reviewed and analysed. The ratio of creatinine clearance/inulin clearance increased progressively with the decline in inulin clearance, while the finding of a normal endogenous creatinine clearance masked a definite but mild decrease of glomerular filtration rate in $42 \%$ of the patients and a moderate decrease of glomerular filtration rate in $23 \%$. This indicates that with declining glomerular filtration rates the endogenous creatinine clearance progressively overestimates actual glomerular filtration rates. Hence a single determination of creatinine clearance can be misleading as a screening measurement of glomerular filtration rate.
\end{abstract}

\section{Introduction}

Inulin clearance is accepted as the most accurate method for the measurement of glomerular filtration rate in man. In certain mammals the clearance of creatinine also measures glomerular filtration rate ; in man, however, definite tubular secretion of creatinine occurs in addition to filtration. Creatinine clearance in man has therefore usually been found to be higher than inulin clearance, both in health (Miller and Winkler, 1938 ; Brod and Sirota, 1948 ; Hare et al., 1949 ; Smith, 1951 ; Mattar et al., 1952) and in disease (Miller and Winkler, 1938 ; Brod and Sirota, 1948 ; Hare et al., 1949 ; Smith, 1951 ; Mattar et al., Miller et al., 1952 ; Berlyne et al., 1964 ; Vere and Walduck, 1964).

Despite this reliability, inulin clearance has not been used routinely for evaluation of glomerular filtration rate because it is technically difficult, is time-consuming, and requires bladder catheterization and constant intravenous infusion. It is understandable that some investigators have proposed the use of endogenous creatinine clearance as an alternative for estimating glomerular filtration rate in man.

Miller and Winkler (1938) found that endogenous creatinine clearance was equal to inulin clearance in several normal subjects. In four patients with renal disease, however, the creatinine clearance was greater than inulin clearance (Miller and Winkler, 1938). Brod and Sirota (1948) reported good agreement between endogenous creatinine clearance (chromogen) and inulin clearance in 14 normal subjects and in 13 patients

* Senior Instructor in Medicine and Director of Renal Research Laboratory, Section of Nephrology and Vascular Diseases, Department of Medicine, Hahnemann Medical College and Hospital, Philadelphia,
Pennsylvania. t Associate Professor of Medicine and Director, Division of Hypertension,
Section of Nephrology and Vascular Disease, Department of Medicine, Hahnemann Medical College and Hospital, Philadelphia, Penn-
sylvania.

₹Chief of Nephrology, Veterans Administration Hospital, San Juan, Puerto Rico.

$\checkmark$ Professor of Medicine and Head of Division of Cardiology, Department of Medicine, Jefferson Medical College Hospital, Philadelphia,

Pennsylvania.
II Associate Professor of Medicine and Head of Section of Nephrology and Vascular Diseases, Department of Medicine, Hahnemann Medical College and Hospital, Philadelphia, Pennsylvania. with renal disease. They concluded that endogenous creatinine clearance may be used as an index of glomerular filtration rate in normal adults and a useful clinical approximation in patients with renal disease. More recently, creatinine/inulin clearance ratios between 0.85 and 1.42 were found in 10 patients (Tobias et al., 1962) and these workers concluded that the endogenous creatinine clearance compared favourably in accuracy and reliability with inulin clearance; they felt that endogenous creatinine clearance provided a valuable clinical estimate of glomerular filtration rate and was a useful prognostic guide in patients with chronic renal disease.

In direct contrast with the above studies, endogenous creatinine clearance was found to differ so significantly from inulin clearance in a series of nine patients with renal disease or congestive heart failure that it could not be considered a satisfactory measure of glomerular filtration rate (Miller et al., 1952). Similarly, the ${ }^{C}$ creatinine $/{ }^{C}$ inulin ratio in 14 patients with renal disease was found to be highly variable and unpredictable (Doering et al., 1953). In six patients with renal disease the creatinine/inulin clearance ratios ranged between 0.97 and 2.37 (Berlyne et al., 1964), and these workers concluded that the ratio was not predictable and that the endogenous creatinine clearance was not a reliable measure of glomerular filtration rate in patients with renal disease.

Those investigators who favour the clinical usefulness of endogenous creatinine clearance point out the following advantages: (1) the test is easily performed, requiring only a single blood sample and a timed collection of urine without catheterization ; (2) intravenous infusion of foreign substances is not required; (3) the laboratory determinations are within the technical capability of most clinical laboratories ; (4) the study is inexpensive, is harmless, and may be repeated as often as desired ; and (5) it provides a sufficiently accurate estimate of glomerular filtration rate so that the clinician may determine the extent of impaired filtration and follow the course of a given renal disease with serial determinations. Those who argue against the usefulness of endogenous creatinine clearance claim that the study often overestimates glomerular filtration rate by 25 to $100 \%$ and therefore does not offer a sufficiently precise estimate of renal damage to allow a reliable follow-up of the clinical course.

Despite 30 years of clinical experience with creatinine clearance since it was originally introduced by Popper and Mandel (1937), its reliability continues to be questioned. Some of the disagreement may be attributed to the relatively small series of different renal diseases reported by each laboratory. We have therefore elected to review our data obtained from 308 simultaneous determinations of endogenous creatinine, inulin, and para-aminohippurate clearance in 250 persons, including normals and patients with various renal diseases. Thirty-one of the patients had from two to six follow-up determinations. These studies cover a total of six years' experience. No changes in the laboratory methods employed over the past six years have been made and all chemical determinations have been performed by the same two chemistry technicians.

The purpose of the present study is to examine the validity of endogenous creatinine clearance and specifically to answer three questions. (1) Can endogenous creatinine clearance within the normal range mask a significant reduction in glomerular 
filtration rate? (2) Are serial determinations of endogenous creatinine clearance useful in evaluating progressive deterioration of glomerular filtration rate in a given patient? (3) If serial changes in endogenous creatinine clearance correlate well with the direction of change in inulin clearance, does serial endogenous creatinine clearance give a better estimate of direction of change in inulin clearance than serial serum creatinine itself ?

\section{Materials and Methods}

Three hundred and eight simultaneous determinations of endogenous creatinine, inulin, and para-aminohippurate clearance were performed in 250 persons over the past six years. Of these, 31 underwent two or more follow-up studies. All studies were performed in the morning or early afternoon with the patient in the supine position. No attempt at fasting was made. Thirty minutes before the beginning of the procedure the subject was given $500 \mathrm{ml}$. of tap-water. Standard priming doses of inulin $(30 \mathrm{mg} . / \mathrm{kg}$.) and para-aminohippurate $(4 \mathrm{mg}$./ kg.) were given intravenously, followed by a constant intravenous infusion of inulin and para-aminohippurate in normal saline throughout the study. A 45-minute equilibration was allowed after the priming dose before starting urine collections. Urine collections were made through an indwelling catheter. Complete urine collections were assured by bladder washout with $50 \mathrm{ml}$. of sterile distilled water followed by $50 \mathrm{ml}$. of air. Each study consisted of a minimum of three 20-minute clearance periods with blood drawn at the midpoint of each period. Inulin concentrations were determined by the method of Roe et al. (1949) and total creatinine (chromogen) was measured by the Bonsnes and Taussky (1945) modification of the Jaffe reaction.

\section{Results}

Normal Values.-Normal values were determined from 37 persons selected because of the absence of cardiac or renal disease ascertained by history, physical examination, and routine urinalysis (Table I). This group, which consisted of normal volunteers and prospective kidney transplant donors, included both men and women aged 20 to 68 . These normal values are consistent with the findings reported in similar studies (Doolan et al., 1962 ; Tobias et al., 1962).

TABLE I.-Values of Creatinine Clearance and Inulin Clearance in 37 Normal Men and Women Aged 20-68 Years

\begin{tabular}{|c|c|c|}
\hline & Mean Value (ml./min.) & Standard Deviation \\
\hline $\begin{array}{l}\text { Creatinine clearance: } \\
\text { Actual value } \ldots \\
\text { Corrected to a standard surface } \\
\text { area of } 1.73 \text { sq. } m . \quad \ldots\end{array}$ & $\begin{array}{l}111 \\
110\end{array}$ & $\begin{array}{l}21 \\
18\end{array}$ \\
\hline $\begin{array}{l}\text { Inulin clearance: } \\
\text { Actual value } \\
\text { Corrected to a standard surface } \\
\text { area of } 1.73 \text { sq. } m . \quad . . \quad \ldots\end{array}$ & 94 & $\begin{array}{l}17 \\
16\end{array}$ \\
\hline $\mathrm{C}_{\mathrm{Cr}} / \mathrm{C}_{\mathrm{in}}$. & $1 \cdot 18$ & $0 \cdot 18$ \\
\hline
\end{tabular}

Ratio of Creatinine Clearance to Inulin Clearance at Various Levels of Glomerular Filtration Rate in Patients with Renal Disease.-The ratios ${ }^{\mathrm{C}}$ creatinine $/{ }^{\text {Cinulin }}$ at various levels of inulin clearance are summarized in Table II. It is apparent from these studies that with declining glomerular filtration rate (Cinulin), the ${ }^{C}$ creatinine/Cinulin ratio progressively increases for any given inulin clearance. In addition, at all levels of inulin clearance a wide scatter of values of ${ }^{{ }^{c}}$ creatinine/ $C_{\text {inulin }}$ ratio was noted, with several inulin clearances being less than one-half of the simultaneously determined creatinine clearance.

Value of Single Determination of Creatinine Clearance. Incidence of Clinical Error.-The number of times that a "normal endogenous creatinine clearance" would suggest a normal glomerular filtration rate and thereby mislead the clinician is demonstrated in Table III. Inulin clearances of
61-70 $\mathrm{ml} . / \mathrm{min}$. have been defined arbitrarily as "definite reduction of glomerular filtration rate," inulin clearances of 51-60 $\mathrm{ml} . / \mathrm{min}$. as " moderate reduction of glomerular filtration rate," and inulin clearance of $50 \mathrm{ml} . / \mathrm{min}$. or less as "severe reduction in glomerular filtration rate." In addition, " normal creatinine clearance" has been defined as creatinine clearance of $90 \mathrm{ml}$./ min. or above, and "decreased creatinine clearances" as values below $90 \mathrm{ml} . / \mathrm{min}$. In Table III the degree of reduction of

TABLE II.-Ratio of Creatinine Clearance to Inulin Clearance with

\begin{tabular}{|c|c|c|c|c|}
\hline $\begin{array}{c}\text { CInuiin } \\
\text { (ml./min.) }\end{array}$ & $\begin{array}{l}\text { Mean Value } \\
\text { of } \mathrm{C}_{\mathrm{Cr}} / \mathrm{C}_{\text {In }} \text {. }\end{array}$ & $\begin{array}{l}\text { Standard } \\
\text { Deviation }\end{array}$ & $\begin{array}{l}\text { Range of } \\
\mathrm{C}_{\mathrm{Cr} .} / \mathrm{C}_{\text {In }} \text {. }\end{array}$ & $\begin{array}{c}\text { No. of } \\
\text { Determinations }\end{array}$ \\
\hline $\begin{array}{l}\geqslant 90 \\
89-70 \\
69-50 \\
49-30 \\
\leqslant 29\end{array}$ & $\begin{array}{l}1.23 \\
1.28 \\
1.36 \\
1.58 \\
1.61\end{array}$ & $\begin{array}{l}0.19 \\
0.20 \\
0.26 \\
0.31 \\
0.34\end{array}$ & $\begin{array}{l}0 \cdot 74-1 \cdot 82 \\
0 \cdot 71-2 \cdot 21 \\
0 \cdot 84-2 \cdot 56 \\
0 \cdot 72-2 \cdot 17 \\
1 \cdot 06-2 \cdot 80\end{array}$ & $\begin{array}{l}85 \\
81 \\
72 \\
45 \\
25\end{array}$ \\
\hline
\end{tabular}

glomerular filtration rate is matched with the number of patients of each group who exhibited a " normal creatinine clearance" (90 $\mathrm{ml} . / \mathrm{min}$. or above) and a "decreased creatinine clearance" (less than $90 \mathrm{ml} . / \mathrm{min}$.). A total of 140 patients with primary renal parenchymal disease, essential hypertension, or congestive heart failure were so compared.

TABLE III.-Value of a Single CCreatinine Determination. Incidence of Normal CCreatinine in Patients with Reduced Glomerular Filtration Rates

\begin{tabular}{|c|c|c|c|c|}
\hline \multirow{2}{*}{\multicolumn{2}{|c|}{$\begin{array}{c}\text { Degree of } \\
\text { Reduction of G.F.R. }\end{array}$}} & \multicolumn{2}{|c|}{ Creatinine Clearance } & \multirow{2}{*}{$\begin{array}{l}\text { No. of } \\
\text { Patients } \\
\text { Studied }\end{array}$} \\
\hline & & $\begin{array}{l}\text { “Normal." } \\
\geqslant 90 \mathrm{ml} . / \mathrm{min} .\end{array}$ & $\begin{array}{l}\text { " Abnormal." } \\
\text { < } 90 \mathrm{ml} \text {./min. }\end{array}$ & \\
\hline $\begin{array}{l}\text { Definite }\left(\mathrm{C}_{\text {In. }} 61-70 \mathrm{ml} . / \mathrm{min} .\right) \\
\text { Moderate }\left(\mathrm{C}_{\text {In. }} 51-60 \mathrm{ml} . / \mathrm{min} .\right) \\
\text { Severe }\left(\mathrm{C}_{\text {In }} \leqslant 50 \mathrm{ml} . / \mathrm{min} .\right)\end{array}$ & $\because$ & $\begin{array}{c}16(42 \%) \\
7(23 \%) \\
1(1 \%)\end{array}$ & $\begin{array}{l}22(58 \%) \\
23(77 \%) \\
71(99 \%)\end{array}$ & $\begin{array}{l}38 \\
30 \\
72\end{array}$ \\
\hline
\end{tabular}

Value of Serial Creatinine Clearance for Follow-up.-The serial data of inulin clearance and endogenous creatinine clearance obtained in 31 patients show that despite pronounced differences between the clearance of endogenous creatinine and the clearance of inulin in the individual patient the direction of change of the two clearances during the follow-up period shows good agreement (Table IV). That is, serial determinations of endogenous creatinine clearance regularly paralleled the rise or fall of actual glomerular filtration rate. Five representative cases are graphically presented in the Chart.

Value of Serial Creatinine for Follow-up.-An analysis of the serial serum creatinine determinations for follow-up in the

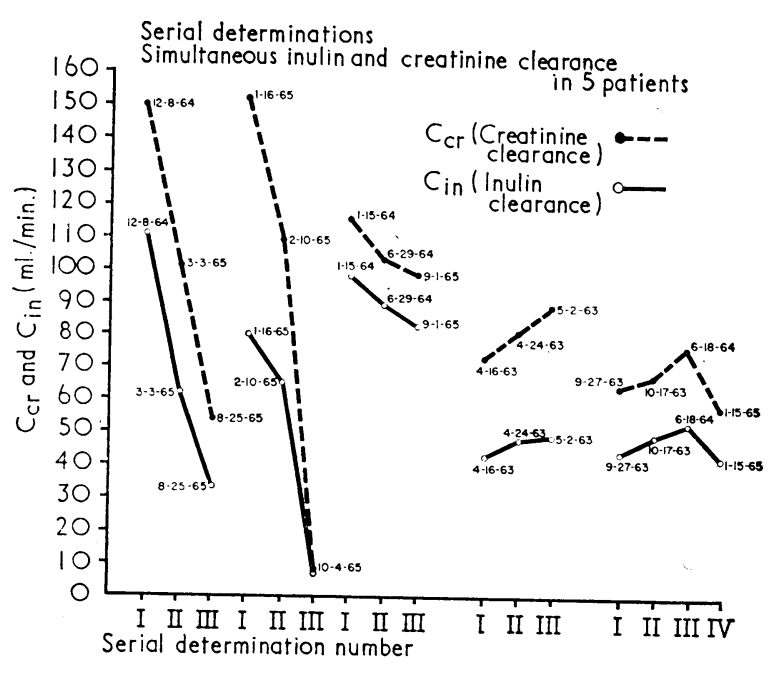

Despite pronounced discrepancies of the two determinations, there is a good agreement between the direction of the changes of insulin clearance and creatinine clearance in each patient. 
TABLE IV.-Serial Determinations of Simultaneous Serum Creatinine (Scr.) in $\mathrm{mg} . / 100 \mathrm{ml}$. and Inulin and Creatinine Clearances in $\mathrm{ml}$./ min.

\begin{tabular}{|c|c|c|c|c|c|c|c|}
\hline \multirow{2}{*}{$\begin{array}{l}\text { Case } \\
\text { No. }\end{array}$} & \multicolumn{7}{|c|}{ Serial Determination } \\
\hline & & I & II & III & IV & V & VI \\
\hline \multirow{3}{*}{1} & $\mathrm{C}_{\mathrm{Cr}}$. & 150 & 101 & 54 & & & \\
\hline & $\mathrm{C}_{\mathrm{In} .}$ & 111 & 62 & 33 & & & \\
\hline & Scr. & & 1.3 & $2 \cdot 1$ & & & \\
\hline & $\mathrm{C}_{\mathrm{Cr} .}$ & 152 & 99 & 8 & & & \\
\hline 2 & $\begin{array}{l}\mathrm{C}_{\text {In. }} \\
\text { Scr. }\end{array}$ & $\begin{array}{l}80 \\
0.8\end{array}$ & $\begin{array}{l}65 \\
1 \cdot 1\end{array}$ & $\begin{array}{c}7 \\
16 \cdot 2\end{array}$ & & & \\
\hline & $\mathrm{C}_{\mathrm{Cr}}$. & 115 & 103 & 98 & & & \\
\hline 3 & $\mathrm{C}_{\mathrm{In} \text {. }}$ & 98 & 89 & 82 & & & \\
\hline & Scr. & 0.8 & 0.8 & 0.8 & & & \\
\hline 4 & $\mathrm{C}_{\mathrm{Cr}}$. & $\begin{array}{r}110 \\
87\end{array}$ & $\begin{array}{l}86 \\
65\end{array}$ & $\begin{array}{l}94 \\
82\end{array}$ & & & \\
\hline & Scr. & 0.8 & 0.8 & 0.7 & & & \\
\hline & $\mathrm{C}_{\mathrm{Cr} .}$ & 97 & 79 & 88 & 18 & 13 & \\
\hline 5 & $\begin{array}{l}C_{\text {In }} \\
\text { Scr. }\end{array}$ & $\begin{array}{l}68 \\
0.9\end{array}$ & $\begin{array}{c}55 \\
0.9\end{array}$ & $\begin{array}{l}65 \\
1.0\end{array}$ & $\begin{array}{l}11 \\
3.8\end{array}$ & $\begin{array}{l}9 \\
3.6\end{array}$ & \\
\hline & $\mathrm{C}_{\mathrm{Cr}}$. & 75 & 56 & & & & \\
\hline 6 & $\begin{array}{l}C_{\text {In. }} \\
\text { Scr. }\end{array}$ & $\begin{array}{l}52 \\
1.2\end{array}$ & $\begin{array}{l}41 \\
1.3\end{array}$ & & & & \\
\hline & $\mathrm{C}_{\mathrm{Cr}}$. & 101 & 132 & 104 & 113 & 120 & 118 \\
\hline 7 & $\mathrm{C}_{\mathrm{In} .}$ & 60 & 122 & 99 & 104 & 100 & 95 \\
\hline & Scr. & 0.9 & 0.7 & 0.9 & 0.9 & 0.7 & 0.7 \\
\hline & $\mathrm{C}_{\mathrm{Cr}}$. & 151 & 155 & 135 & 125 & 139 & 136 \\
\hline 8 & $\mathrm{C}_{\mathrm{In}}$. & 118 & 126 & 101 & 83 & 108 & 102 \\
\hline & Scr. & $\begin{array}{r}0.9 \\
73\end{array}$ & $1 \cdot 0$ & $1 \cdot 1$ & 1.0 & $1 \cdot 1$ & 0.9 \\
\hline 9 & $\mathrm{C}_{\mathrm{Tn}}^{\mathrm{Cr}}$. & $\begin{array}{l}73 \\
66\end{array}$ & $\begin{array}{l}97 \\
82\end{array}$ & $\begin{array}{l}91 \\
81\end{array}$ & & & \\
\hline & Scr. & $1 \cdot 0$ & 0.9 & $1 \cdot 0$ & - & & \\
\hline & $\mathrm{C}_{\mathrm{Cr}}$. & 72 & 88 & 80 & & & \\
\hline 10 & $\mathrm{C}_{\text {In }}$. & 42 & 48 & 47 & & & \\
\hline & Scr. & 161 & $161 \cdot 0$ & $191^{1 \cdot 0}$ & & & \\
\hline 11 & $\mathrm{C}_{\mathrm{In} \text {. }}^{\mathrm{Or}}$ & 130 & 130 & 146 & & & \\
\hline & Scr. & $1 \cdot 1$ & 0.8 & 0.8 & & & \\
\hline & $\mathrm{C}_{\mathrm{Cr}}$. & 97 & 141 & 130 & & & \\
\hline 12 & $\mathrm{C}_{\mathrm{In} .}$ & 61 & 99 & 90 & & & \\
\hline & Scr. & 0.9 & 0.7 & 1.0 & & & \\
\hline & $\mathrm{C}_{\mathrm{Cr} .}$ & 67 & 75 & & & & \\
\hline 13 & $\mathrm{C}_{\mathrm{In} .}$ & 55 & 65 & & & & \\
\hline & $\begin{array}{l}\text { Scr. } \\
C_{C r} .\end{array}$ & $\begin{array}{l}1 \cdot 0 \\
94\end{array}$ & 38 & & & & \\
\hline 14 & $\mathrm{C}_{\mathrm{In} .}$ & 62 & 26 & & & & \\
\hline & Scr. & 1.0 & $1 \cdot 7$ & & & & \\
\hline & $\mathrm{C}_{\mathrm{Cr} .}$ & 66 & 57 & & & & \\
\hline 15 & $\mathrm{C}_{\mathrm{In} .}$ & 58 & 53 & & & & \\
\hline & Scr. & 0.8 & 1.0 & & & & \\
\hline & $\mathrm{C}_{\mathrm{Cr}}$. & 65 & 57 & & & & \\
\hline 16 & $\begin{array}{l}C_{\text {In. }} \\
\text { Scr. }\end{array}$ & $\begin{array}{l}60 \\
0.8\end{array}$ & $\begin{array}{l}50 \\
0.9\end{array}$ & & & & \\
\hline & $\mathrm{C}_{\mathrm{Cr}}$ & 80 & 85 & & & & \\
\hline 17 & $\mathrm{C}_{\mathrm{In} .}$ & 73 & 77 & & & & \\
\hline & Scr. & 0.7 & 0.7 & & & & \\
\hline & $\mathrm{C}_{\mathrm{Or}}$. & 99 & 105 & & & & \\
\hline 18 & $\mathrm{C}_{\mathrm{In} .}$ & 88 & 99 & & & & \\
\hline & Scr. & $\begin{array}{c}0 \cdot 7 \\
71\end{array}$ & $61^{0.5}$ & & & & \\
\hline 19 & $\mathrm{C}_{\text {In }}$. & 69 & 47 & & & & \\
\hline & Scr. & 0.9 & 0.9 & & & & \\
\hline & $\mathrm{C}_{\mathrm{Cr} .}$ & 86 & 87 & & & & \\
\hline 20 & $\mathrm{C}_{\mathrm{In} .}$ & 43 & 49 & & & & \\
\hline & Scr. & $1 \cdot 4$ & 1.6 & & & & \\
\hline & $\mathrm{C}_{\mathrm{Cr}}$. & 100 & 67 & & & & \\
\hline 21 & $C_{\text {In. }}$ & 57 & 46 & & & & \\
\hline & Scr. & $0 \cdot 8$ & $1 \cdot 1$ & & & & \\
\hline 22 & $\mathrm{C}_{\mathrm{Cr}}$. & $\begin{array}{l}80 \\
61\end{array}$ & $\begin{array}{l}90 \\
72\end{array}$ & & & & \\
\hline & Scr. & 0.9 & 1.0 & & & & \\
\hline & $\mathrm{C}_{\mathrm{Cr}}$. & 105 & 112 & & & & \\
\hline 23 & $\mathrm{C}_{\mathrm{In}}$ & 99 & 100 & & & & \\
\hline & Scr. & 0.9 & 0.7 & & & & \\
\hline & $\mathrm{C}_{\mathrm{Cr}}$. & 100 & 100 & & & & \\
\hline 24 & $\mathrm{C}_{\mathrm{In} .}$ & 62 & 63. & & & & \\
\hline & Scr. & 0.7 & 1.0 & & & & \\
\hline & $\mathrm{C}_{\mathrm{Cr} .}$ & 115 & 95 & & & & \\
\hline 25 & $\mathrm{C}_{\mathrm{In}}$. & 103 & 70 & & & & \\
\hline & Scr. & 0.9 & 0.9 & & & & \\
\hline & $\mathrm{C}_{\mathrm{Cr}}$. & 50 & 49 & & & & \\
\hline 26 & $\mathrm{C}_{\mathrm{In} .}$ & 25 & 28 & & & & \\
\hline & Scr. & 1.8 & 1.6 & & & & \\
\hline & $\mathrm{C}_{\mathrm{Or}}$. & 114 & 115 & & & & \\
\hline 27 & $\mathrm{C}_{\text {In }}$. & 80 & 83 & & & & \\
\hline & Scr. & 0.8 & 0.8 & & & & \\
\hline 28 & $\mathrm{C}_{\mathrm{Cr}}$. & $\begin{array}{l}121 \\
104\end{array}$ & $\begin{array}{r}106 \\
93\end{array}$ & & & & \\
\hline & Scr. & 0.7 & & & & & \\
\hline & $\mathrm{C}_{\mathrm{Cr} .}$ & 184 & 116 & & & & \\
\hline 29 & $\mathrm{C}_{\mathrm{In}}$ & 104 & 81 & & & & \\
\hline & Scr. & $1 \cdot 0$ & 0.9 & & & & \\
\hline & $\mathrm{C}_{\mathrm{Cr}}$. & 83 & 83 & & & & \\
\hline 30 & $\mathrm{C}_{\text {In. }}$ & 72 & 80 & & & & \\
\hline & Scr. & 1.0 & 0.8 & & & & \\
\hline & $\mathrm{C}_{\mathrm{Cr}}$. & 126 & 100 & & & & \\
\hline 31 & $\mathrm{C}_{\mathrm{In}}$. & 89 & 76 & & & & \\
\hline & Ser. & 0.9 & 0.9 & & & & \\
\hline
\end{tabular}

same 31 patients who had had serial inulin and endogenous creatinine clearance showed that six patients (Table IV, Cases 3, $4,13,19,25$, and 31 ) had no changes in serum creatinine concentration despite an inulin clearance decrease or increase of $\underline{\underline{\sigma}}$ 15 to $32 \%$, whereas endogenous creatinine clearance correlated well with the direction of changes in inulin clearance. In $\mathbb{8}$ Case 22 (patient with scleroderma), despite an increase in inulin $\stackrel{\varrho}{c}$ and endogenous creatinine clearance, serum creatinine concentration increased. In case 29 inulin and endogenous creatinine $\stackrel{\vec{\rho}}{\rightarrow}$ clearance decreased whereas, contrary to expectations, serum 0 creatinine concentration also decreased. In Case 24, though $\frac{}{6}$ there was no change in inulin clearance and creatinine clearance, $\frac{\bar{\omega}}{7}$ serum creatinine concentration increased from 0.7 to $1.0 \mathrm{mg} . / \mathbb{8}$ $100 \mathrm{ml}$. These findings indicate that serial determination of endogenous creatinine clearance is a better index of glomerular filtration rate than serial determination of serum creatinine.

\section{Discussion}

Tubular secretion of creatinine in man is well documented (Shannon, 1935 ; Shannon and Ranges, 1941 ; Brod and Sirota, of

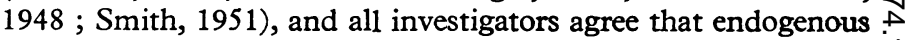
creatinine clearance cannot be regarded as a precise measure of $\overrightarrow{ }$ glomerular filtration rate. It remains controversial, however, 은 whether creatinine clearance provides a sufficiently good esti- $A$ mate to allow the clinician to use this study in the evaluation 0 of glomerular filtration rate. The problem has been made $\frac{?}{0}$ difficult by the variety of techniques employed for the analysis of urine and plasma creatinine.

Three methods of estimating creatinine are most widely used. $\overrightarrow{\mathscr{\theta}}$ The first is the Jaffe reaction, which measures both creatinine. and non-creatinine chromogen (Bonsnes and Taussky, 1945). With the second a " true creatinine" can be obtained by absorbing this chromogen on Fuller's earth (Lloyd"s reagent) (Hare, $\overline{0}$ 1950) or by enzymatic determinations (Miller and Dubos, 1937). The third, a modification of the first technique, has been devised $\Phi$ by utilizing the Technicon Auto-Analyzer (Technicon Instruments Corporation, 1963). Doolan et al. (1962) concluded that $\frac{0}{3}$ the variability of the value in patients with evidence of renal $\vec{r}$ disease was no greater for chromogen creatinine than for true creatinine measurements, that the information provided by means of each method was in close agreement, and that either method is suitable for clinical purposes. A preference, however, was expressed for true creatinine measurements if the plasma values were low normal or less (Doolan et al., 1962).

Healy (1968) demonstrated that the true creatinine clearance $\frac{3}{3}$ bore a better relation to glomerular filtration rate than did manual chromogen creatinine clearance and Auto-Analyzer creatinine clearance. A comparison of three methods of creati- $N$ nine clearance has indicated that in health and disease Auto- $D$ Analyzer chromogen creatinine clearance approached inulin clearance most closely, whereas true creatinine clearance showed $N$ the greater divergence (Rapoport and Husdan, 1968).

We recommend chromogen creatinine clearance by either $\tilde{O}$ method because the determination of chromogen creatinine is 0 much simpler than true creatinine determination and the $\stackrel{D}{\Phi}$ accuracy of endogenous creatinine clearance with different $\stackrel{\infty}{+}$ methods is still controversial.

Our data show that with progressive decline of glomerular $\frac{0}{\mathbb{D}}$ filtration rate the endogenous creatinine clearance tends to $\stackrel{\square}{\mathscr{P}}$ become proportionately higher than the corresponding inulin $\mathbb{D}$ clearance. The creatinine/inulin clearance ratio therefore rises $\bar{\sigma}$ with the decline of inulin clearance. These results are in essential agreement with those obtained by Reubi (1963), who compared endogenous creatinine clearance with the glomerular filtration rate measured by the clearance of thiosulphate. This implies that as inulin clearance declines creatinine clearance progressively overestimates the actual glomerular filtration rate.

Other investigators (Brod and Sirota, 1948 ; Hare et al., 1949 ; Smith, 1951 ; Doering et al., 1953 ; Doolan et al., 1962 ; 
Tobias et al., 1962 ; Berlyne et al., 1964 ; Vere and Walduck, 1964) have reported that the differences between clearance of endogenous creatinine and clearance of inulin may be very small in some patients but in others may approach 50 to $100 \%$. The data from our studies also emphasized this pronounced individual variability. Furthermore, we were unable to detect any individual predictability at different levels of renal function; and no pattern could be established for different groups of renal disease.

In our study $42 \%$ of patients with "definite but mild decrease in glomerular filtration rate" had creatinine clearance above $90 \mathrm{ml} . / \mathrm{min}$. and would have been defined as "normal" if the physician had relied on a single determination of creatinine clearance. These findings emphasize the following essential clinical point: an endogenous creatinine clearance within normal range may often mask the presence of a significant depression of glomerular filtration rate. Reliance on a normal creatinine clearance at one point in time will be misleading in almost half of the patients with definite reduction in glomerular filtration rate.

The analysis of our follow-up study shows that if serial clearance studies are made over the course of time in a given patient the clinical validity of the endogenous creatinine clearance increases substantially. In the 31 patients in whom serial determinations were performed during the course of their disease an excellent correlation was found between the rate of decline or increase in inulin and creatinine clearance.

Several investigators have sought appropriate mathematical transformations of the data which would result in a linear relationship between the two variables (plasma creatinine and endogenous creatinine clearance) in order that the value of the clearance could be predicted from serum creatinine concentration. Effersøe (1957) obtained such a relationship by plotting the logarithm of the plasma concentration against the logarithm of the 24-hour clearance. He concluded that an informative estimate to within $20 \%$ of the actual clearance value could be obtained if the patient had a stable plasma creatinine concentration, but only if the patient was in a non-steady state; if greater accuracy was required, endogenous creatinine clearance measurements had to be performed. Endogenous creatinine clearance can be predicted with sufficient accuracy for most clinical purposes from plasma creatinine concentration (Edwards and Whyte, 1959). A determination of plasma concentration, however, is of limited value in predicting the level of endogenous creatinine clearance, and renal function is more precisely evaluated by relating excretion per unit of time to plasma concentration (Doolan et al., 1962). Furthermore, progressive deterioration of the creatinine clearance was noted in 21 patients with chronic renal disease before death (Tobias et al., 1962). The serum creatinine concentration, however, actually showed improvement during the last six months of life in seven of these patients, possibly in part as a result of relative starvation and decreased muscle mass.

Our studies confirmed that serial determinations of endogenous creatinine clearance often provided information which was not apparent from changes in serum creatinine concentration alone. Serum creatinine concentration is determined by the volume of creatinine distribution, the rate of production (related to muscle mass), and the rate of excretion (primarily glomerular filtration). In patients with muscular atrophy serum creatinine values are proportionally less for a given level of glomerular filtration rate, while in patients with severe oliguria serum creatinine concentration becomes primarily a function of production and volume of distribution.

As Doolan and his colleagues pointed out, glomerular filtration rate is more precisely evaluated by relating excretion per unit of time to plasma concentration (clearance) than by plasma concentration alone.

We propose, therefore, that a normal endogenous creatinine clearance should never be construed as definite evidence of a normal glomerular filtration rate. The significant economic, clinical, and technical advantages of the endogenous creatinine clearance make it useful in following the direction of change of glomerular filtration rate during the course of renal disease. Our data indicate that serial determinations of endogenous creatinine clearance are superior to serial determinations of serum creatinine alone in following changing glomerular filtration rates.

\section{REFERENCES}

Berlyne, G. M., Varley, H., Nilwarangkur, S., and Hoerni, M. (1964). Lancet, 2, 874 .

Bonsnes, R. W., and Taussky, H. H. (1945). fournal of Biological Chemistry, 158, 581 . Brod, J., and Sirota, J. H. (1948). Fournal of Clinical Investigation, 27,

Doering, P., Koch, R., Schroeter, H., and Schwab, M. (1953). Klinische Wochenschrift, 31, 489.

Doolan, P. D., Alpen, E. L., and Theil, G. B. (1962). American fournal of Medicine, 32, 65.

Edwards, K. D. G., and Whyte, H. M. (1959). Australasian Annals of Medicine, 8, 218.

Effersøe, P. (1957). Acta Medica Scandinavica, 156, 429.

Hare, R. S. (1950). Proceedings of the Society of Experimental Biology and Medicine, 74, 148.

Hare, K., Goldstein, H., Barnett, H. L., McNamara, H., and Hare, R. S. (1949). Federation Proceedings, 8, 67.

Healy, J. K. (1968). American fournal of Medicine, 44, 348.

Mattar, G., Barnett, H. L., McNamara, H., and Lauson, H. D. (1952). fournal of Clinical Investigation, 31, 938.

Miller, B. F., and Dubos, R. J. (1937). fournal of Biological Chemistry, 121,447 .

Miller, B. F., Leaf, A., Mamby, A. R., and Miller, Z. (1952). Fournal of Clinical Investigation, 31, 309.

Miller, B. F., and Winkler, A. W. (1938). fournal of Clinical Investigation, 17, 31 .

Popper, H., and Mandel, E. (1937). Ergebnisse dez Inneren Medizin und Kinderheilkunde, 53, 685.

Rapoport, A., and Husdan, H. (1968). Canadian Medical Association fournal, 99, 149.

Reubi, F. C. (1963). Clearance Tests in Clinical Medicine, p. 13. Springfield, Illinois, Thomas.

Roe, J. H., Epstein, J. H., and Goldstein, N. P. (1949). Fournal of Biological Chemistry, 178, 839.

Shannon, J. A. (1935). Fournal of Clinical Investigation, 14, 403.

Shannon, J. A., and Ranges, H. A. (1941). Fournal of Clinical Investigation, 20, 169.

Smith, H. W. (1951). The Kidney: Structure and Function in Health and Disease, p. 182. New York, Oxford University Press.

Technicon Instruments Corporation (1963). Technicon Method N-11a. Estimation of Creatinine. Auto-Analyzer N Methodology. Chauncey, New York.

Tobias, G. J., McLaughlin, R. F., jun., and Hopper, J., jun. (1962). New England fournal of Medicine, 266, 317.

Vere, D. W., and Walduck, A. (1964). Lancet, 2, 1299. 